"Mircea cel Batran" Naval Academy Scientific Bulletin, Volume XIX - 2016 - Issue 1

Published by "Mircea cel Batran" Naval Academy Press, Constanta, Romania // The journal is indexed in:

PROQUEST / DOAJ / DRJI / JOURNAL INDEX / I2OR / SCIENCE LIBRARY INDEX / Google Scholar / Crossref /

Academic Keys / ROAD Open Access / OAJI / Academic Resources / Scientific Indexing Services / SCIPIO

\title{
QUALITY CONTROL IN LOGISTICS ACTIVITIES THROUGH INTERNET OF THINGS TECHNOLOGY
}

\author{
Andrei BAUTU ${ }^{1}$ \\ Elena BAUTU2 \\ ${ }^{1}$ Lecturer, Ph.D., "Mircea cel Batran" Naval Academy, Romania \\ 2Lecturer, Ph.D., "Ovidius" University, Romania
}

\begin{abstract}
Modern companies depend on their logistics in order to maintain their purchases-inventory-sales chain to the desired level of performance (i.e. profitability). Many past situations demonstrate that errors, inefficiencies and disruptions in this chain can cause companies to miss opportunities, loose profitability, and even go bankrupt. An important factor to high quality logistics is the quality and availability of information about key processes. Internet of Things (IOT) technology allows companies to gather real-time information on processes, people and equipment, and to integrate it in their own informational systems. This paper discusses the use of IOT technology to monitor logistics activities in order to provide support data for performance assessments.
\end{abstract}

Keywords: Internet of Things, Logistics, Performance

\section{Introduction}

A popular saying is that logistics means "having the right thing, at the right place, at the right time". In a more traditional business sense, logistics is the component of the business management responsible with planning and implementation of the flow of resources between creation and consumption sites, involving on their way processing and storage [9].

Many companies depend on their logistics component in order to maintain profitability and credibility in front of their business partners [14][6]. The performance of their logistics department is affected by the performance of their suppliers, changes in legislation, unpredictable variations in fuel costs, transportation fees and delays, labor rates, etc [5].

In general, modern companies rely on their logistics to maintain their purchases-inventorysales chain to the desired level of performance, which in turn leads to higher profitability.

The type of resources that businesses use for their operations are varied, but they can be divided into physical items (raw materials, goods, animals, people, cash) and abstract items (time, information, services, credit).

The logistics of the physical items requires additional planning due to physical limitations and special requirements involved in transportation and storage of these items [15][13]. Each one of these steps adds additional complexity to the logistic plan as there are many variables to consider. For example, transportation can be done by air, by sea or by ground, via multiple routes, in bulk or in packages, with regular shipments or with special deliveries, etc [8]. Similarly, storage of physical items can be done in different warehouses along the routes, each one

DOI: 10.21279/1454-864X-16-I1-004

(c) 2015. This work is licensed under the Creative Commons Attribution-Noncommercial-Share Alike 4.0 License. with particular storage limits and capabilities. Therefore, an important part in the logistics implementation is control, the part that ensures that the flow of items is following the plan and takes corrective actions in case it does not [7]. An essential aspect of the quality control in logistics is access to real-time data that provides the visibility on resources and transactions needed for making informed decisions.

In this paper we review the Internet of Things concept and discuss some possible applications in logistics and transportation businesses.

IT\&C in Logistics

During the past decades, more and more companies implemented IT\&C solutions in their logistics process in order to reduce the informational lag and raise productivity [12]. Apart from computer software and hardware, such solutions vary in complexity from simple barcode labels and automated storage and retrieval system (AS/RS).

The technical advances in mobile technologies from the last decade provide even small companies with the communication infrastructure that can support mobile, reliable, high-speed data transfers at affordable prices. This is one of the requirements for real-time data and information.

The mobile technologies also brought to market a concept that has been proposed and researched since early 2000: the Internet of Things (IOT) [16]. Internet of Things

Internet of Things (IOT) was defined by ITU as "a global infrastructure for the information society, enabling advanced services by interconnecting (physical and virtual) things based on existing and evolving interoperable information and communication technologies" [19]. 
"Mircea cel Batran" Naval Academy Scientific Bulletin, Volume XIX - 2016 - Issue 1

Published by "Mircea cel Batran" Naval Academy Press, Constanta, Romania // The journal is indexed in: PROQUEST / DOAJ / DRJI / JOURNAL INDEX / I2OR / SCIENCE LIBRARY INDEX / Google Scholar / Crossref /

Academic Keys / ROAD Open Access / OAJI / Academic Resources / Scientific Indexing Services / SCIPIO

With IoT, the Internet no longer connects only computers-like devices, but it also connects "things" - physical objects that can send and receive data through embedded electronics, software, and sensors [17]. Therefore, with IoT, the Internet is no longer used for communication only by people, but it is also used by things to communicate, machine-to-machine (M2M) [1].

\section{IoT in Logistics}

The advantages of IOT have already been noted by early adopters of the IOT concept. In a recent study published by Zebra Technologies, the authors report that between 2012 and 2014 among the 593 companies from 16 countries interviewed for the study, the percentage that have deployed at least one IOT solution raised from 15 to $65 \%$, while the number of deployments of loT solutions have tripled [20].

Another study published by Cisco Consulting Service estimates that over the next decade IoT will generate $\$ 1.9$ trillion revenue worldwide in supply chain and logistics alone [21]

IoT can transform traditionally unconnected objects from the real world, called "dark assets", into connected things, releasing the potential information of these assets. In general, the added value of IOT for businesses is the data captured from connected things, which can raise productivity, increase profitability, accelerate operations, or even help redesign the business [10][4]. The real-time data about the operations of the company offers real-time visibility on its operations, while logged data can be analyzed to provide new insights which will drive business and operational transformation. With their real-time data feeds and cloud-based historical data stores, the network of connected assets can improve the quality control throughout the entire supply chain, essentially improving the entire logistics process of any company.

Table 1 provides an overview of some IoT components that could be employed in the supply chain for quality control.

\begin{tabular}{|l|l|l|}
\hline $\begin{array}{l}\text { Type of } \\
\text { sensor }\end{array}$ & $\begin{array}{l}\text { Dark } \\
\text { assets }\end{array}$ & Possible usage \\
\hline RFID tags & $\begin{array}{l}\text { inventory, } \\
\text { equipment, } \\
\text { people }\end{array}$ & $\begin{array}{l}\text { sensing and } \\
\text { identification of } \\
\text { physical entities }\end{array}$ \\
\hline IP cameras & equipment & $\begin{array}{l}\text { Visual inspection } \\
\text { and identification } \\
\text { of damage items }\end{array}$ \\
\hline GPS & $\begin{array}{l}\text { equipment } \\
\text { (vehicles), } \\
\text { inventory } \\
\text { (containers } \\
\text { or valuable } \\
\text { items) }\end{array}$ & $\begin{array}{l}\text { Track fleet and } \\
\text { equipment to } \\
\text { ensure correct } \\
\text { usage or locate lost/stolen } \\
\text { locand and } \\
\text { equipment and } \\
\text { stock }\end{array}$ \\
\hline
\end{tabular}

\begin{tabular}{|c|c|c|}
\hline $\begin{array}{l}\text { Type of } \\
\text { sensor }\end{array}$ & $\begin{array}{l}\text { Dark } \\
\text { assets }\end{array}$ & Possible usage \\
\hline $\begin{array}{l}\text { In-vehicle } \\
\text { telematics } \\
\text { (acceleration, } \\
\text { load, }\end{array}$ & $\begin{array}{l}\text { equipment } \\
\text { (vehicles) }\end{array}$ & $\begin{array}{l}\text { Log and monitor } \\
\text { the correct usage } \\
\text { of equipment }\end{array}$ \\
\hline $\begin{array}{l}\text { vehicle } \\
\text { infrastructure } \\
\text { (vibration, } \\
\text { usage) }\end{array}$ & $\begin{array}{l}\text { equipment } \\
\text { (vehicles) }\end{array}$ & $\begin{array}{l}\text { Log and monitor } \\
\text { the technical } \\
\text { state } \\
\text { equipment }\end{array}$ \\
\hline $\begin{array}{l}\text { road/gates } \\
\text { sensors }\end{array}$ & $\begin{array}{l}\text { equipment, } \\
\text { yard }\end{array}$ & $\begin{array}{l}\text { Avoid delays } \\
\text { caused by traffic } \\
\text { jams; balance } \\
\text { load } \\
\text { inbound/outbound } \\
\text { gates; manage } \\
\text { parking spots }\end{array}$ \\
\hline $\begin{array}{l}\text { environmental } \\
\text { (temperature, } \\
\text { humidity, air } \\
\text { quality, etc) }\end{array}$ & $\begin{array}{l}\text { inventory } \\
\text { equipment } \\
\text { (containers, } \\
\text { vehicles) } \\
\end{array}$ & $\begin{array}{l}\text { Monitor } \\
\text { environmental } \\
\text { status and control } \\
\text { HVAC systems }\end{array}$ \\
\hline $\begin{array}{l}\text { radar and } \\
\text { proximity } \\
\text { sensors }\end{array}$ & equipment & $\begin{array}{l}\text { Proximity } \\
\text { detection } \\
\text { collision } \\
\text { avoidance }\end{array}$ \\
\hline
\end{tabular}

Table 1. Usages of IoT components for quality control in the supply chain

We will present next a few scenarios of IoT implementations for logistics purposes. One of the main applications of IoT in logistics is related to automatic identification of entities (people, resources, stock). Let's consider the use case of stock passing thought warehouses (and storage yards) on its way to the end customer. Warehouses are an important part of the any logistics business, and therefore its organization affects the performance of the supply chain, which impacts the profitability and competitiveness of the business.

In their case, the things that IoT will connect can be warehouse inventory, equipment (meters, scales, storage locations, forklifts, etc), and personnel.

An important part of the warehouse operations involve keeping track of the inventory. This can be done automatically, by using wireless receivers and tags with miniaturized transmitters, like those based on Radio-frequency identification (RFID) technology. Each item or pallet is tagged when arriving at the warehouse (either by the supplier or by the warehouse owner). While moving around the warehouse, tags are repeatedly scanned to update the locations of the products and to avoid misplacing them. Tags contain information about the product type and its physical attributes (weight, volume, counts, etc) which can be used by the warehouse management system to ensure 


\section{"Mircea cel Batran" Naval Academy Scientific Bulletin, Volume XIX - 2016 - Issue 1 \\ Published by "Mircea cel Batran" Naval Academy Press, Constanta, Romania /I The journal is indexed in: PROQUEST / DOAJ / DRJI / JOURNAL INDEX / I2OR / SCIENCE LIBRARY INDEX / Google Scholar / Crossref / \\ Academic Keys / ROAD Open Access / OAJI / Academic Resources / Scientific Indexing Services / SCIPIO}

available stocks are within the safely limits. Finally, the tags are useful even when and after the stock is leaving the inventory. They allow the warehouse management system (WMS) [12] to check that the right products are being delivered and that the database inventory matches the onsite situation, they allow the customers to track the locations of their products and estimate delivery times, etc.

Using the same technology, but in a different use case, we consider the case of loT-connected stock, but we focus on the space limitations of warehouses, storage yards, and transportation. Once a virtual representation of the stock is available in IOT, it can be used for various optimization and analytics. For example, the WMS software can use information about physical dimensions of the products to decide their exact storage location. This could lead to significant profitability gain as it could reduce overall space requirement, equipment usage, waiting times, etc. Moreover, since the virtual model can "arrive" in the WMS before the physical object arrives at the inbound gates of the warehouse, optimizations and storage preparations can begin before the actual arrival, earning some valuable time.

Another technology that can be employed for quality control is video IP cameras or laser scanners, and visual recognition software. Such systems are already in used in manufacturing environments to detect imperfections in products during the manufacturing process. With IoT, they can be integrated into the supply chain to provide visual inspection of stock along the route to the end-user. For example, these can be located at the inbound gates of warehouses in order to identify items or pallets that have been damaged during transportation, or at the outbound gates to identify items/pallets that have been damaged during storage.

Live stock and some products types (plants, food, etc) require special storage conditions (humidity, light, temperature, noise, air quality) [11][15][3]. This is an important issue for providing quality services for these products (in addition usual logistics factors, like delay times, transportation costs, security, etc). Sensors can be employed for monitoring these parameters in storage and transportation environments. Before IoT, such solutions were expensive and require some level of human intervention. Due to consumerization of sensors technology, various manufacturers already offer affordable system-on-chip solutions for tracking environmental parameters that are IoT-enabled and scientific research on this topic will provide more features and better products [2] Fleet management is another part of the logistics process that has benefited from IT\&C over the years. Many transportation and logistics businesses nowadays rely on electronic cargo sheets, electronic time sheets and GPS devices to monitor and secure their fleet. However, modern transportation vehicles are equipped with onboard computers that can provide much more information about the state of the vehicle. Turning these dark assets into connected things unlocks information that can lower the usage of human and technical resources in the logistics business (some automotive builders, like Tesla, General Motors and Audi, are already doing it for their own gain [18]).

\section{CONCLUSIONS}

The IT\&C solutions have allowed logistics and transportation business to grow to such levels that would not have been possible with it, while at the same time expanding the range of services offered to their customers. The growth would not have been possible for many reasons, the amount of manual labor and the volume of data being some of them. The IT\&C solutions were able to solve these problems in an efficient way until now, but they are reaching their limits. The Internet of Things is the next step on this technological path as it removes the human factor from data creation and opens new data sources through dark assets turned into connected things. For logistics business this additional information could lead to competitive advantage and profit growth, the same way IT\&C did it a few decades back. Moreover, the new data streams could offer unprecedented real-time visibility over the entire supply chain, which can reduce operational costs while maintaining or even increasing the quality of the services.

\section{BIBLIOGRAPHY}

[1] Adnan Aijaz and A. Hamid Aghvami. "Cognitive machine-to-machine communications for internet-ofthings: a protocol stack perspective." Internet of Things Journal, IEEE 2.2 (2015): 103-112.

[2] Amir Atabekov et al. "Internet of Things-based Temperature Tracking System." Computer Software and Applications Conference (COMPSAC), 2015 IEEE 39th Annual. Vol. 3. IEEE, 2015.

[3] Mihai Doinea, et al. "Internet of Things Based Systems for Food Safety Management." Informatica Economica 19.1 (2015): 87.

[4] Marco Ferretti and Francesco Schiavone. "Internet of Things and business processes redesign in seaports: The case of Hamburg." Business Process Management Journal 22.2 (2016): 271-284. 


\begin{abstract}
"Mircea cel Batran" Naval Academy Scientific Bulletin, Volume XIX - 2016 - Issue 1 Published by "Mircea cel Batran" Naval Academy Press, Constanta, Romania /I The journal is indexed in: PROQUEST / DOAJ / DRJI / JOURNAL INDEX / I2OR / SCIENCE LIBRARY INDEX / Google Scholar / Crossref / Academic Keys / ROAD Open Access / OAJI / Academic Resources / Scientific Indexing Services / SCIPIO
\end{abstract}

[5] Thomas Hamilton, "The State of Logistics Performance Measurement: A Comparison of Literature and Practice." (2015).

[6] Erika Kallionpaa, Nina Helander, and Jarkko Rantala. "Managing tomorrow's daily consumer goods logistics value network." International Journal of Supply Chain and Operations Resilience 1.2 (2015): 201218.

[7] Juntao Li, Weihua Gu, and Hui Wu. "The literature review of research on modeling of automated guided vehicle's picking route." Sixth International Conference on Electronics and Information Engineering. International Society for Optics and Photonics, 2015.

[8] Wenrong Lu et al. "An algorithm for dynamic order-picking in warehouse operations." European Journal of Operational Research 248.1 (2016): 107-122.

[9] Rhonda R. Lummus, Dennis W. Krumwiede, Robert J. Vokurka, (2001) "The relationship of logistics to supply chain management: developing a common industry definition", Industrial Management \& Data Systems, Vol. 101 Iss: 8, pp.426 - 432

[10] Lin Ma, Fengying Nie, and Qian Lu. "An analysis of supply chain restructuring based on Big Data and mobile Internet-A case study of warehouse-type supermarkets." Grey Systems and Intelligent Services (GSIS), 2015 IEEE International Conference on. IEEE, 2015.

[11] Eleonora Morganti and Jesus Gonzalez-Feliu. "City logistics for perishable products. The case of the Parma's Food Hub." Case Studies on Transport Policy 3.2 (2015): 120-128.

[12] Andreas Nettsträter et al. "Logistics Software Systems and Functions: An Overview of ERP, WMS, TMS and SCM Systems." Cloud Computing for Logistics. Springer International Publishing, 2015. 1-11.

[13] Xuan Qiu et al. "Physical assets and service sharing for loT-enabled Supply Hub in Industrial Park (SHIP)." International Journal of Production Economics 159 (2015): 4-15.

[14] Stephen M. Rutner, C. John Langley, Jr, (2000) "Logistics Value: Definition, Process and Measurement", The International Journal of Logistics Management, Vol. 11 Iss: 2, pp.73 - 82

[15] Michael Wagner and Herbert Meyr. "Food and beverages." Supply chain management and advanced planning. Springer Berlin Heidelberg, 2015. 391-407.

[16] Roy Want, Bill N. Schilit, and Scott Jenson. "Enabling the internet of things." Computer 1 (2015): 28-35.

[17] Andrew Whitmore, Anurag Agarwal, and Li Da Xu. "The Internet of Things—A survey of topics and trends." Information Systems Frontiers 17.2 (2015): 261-274.

[18] Naveen Shivaramu Yeshodara, Namratha S. Nagojappa, and Nikhitha Kishore. "Cloud Based Self Driving Cars." Cloud Computing in Emerging Markets (CCEM), 2014 IEEE International Conference on. IEEE, 2014.

[19] ***, Recommendation ITU-T Y.2060 (06/2012) [online], http://www.itu.int/ITUT/recommendations/rec.aspx?rec=y.2060

[20] $* * *$, Internet-of-Things solution deployment gains momentum among firms globally [online], https://www.zebra.com/content/dam/zebra/press-releases/en-us/2014/zebra-tlp-final.pdf

[21] ***, Internet-of-Things will deliver \$1.9 trillion boost to supply chain and logistics operations, [online], https://newsroom.cisco.com/press-release-content?articleld=1621819 